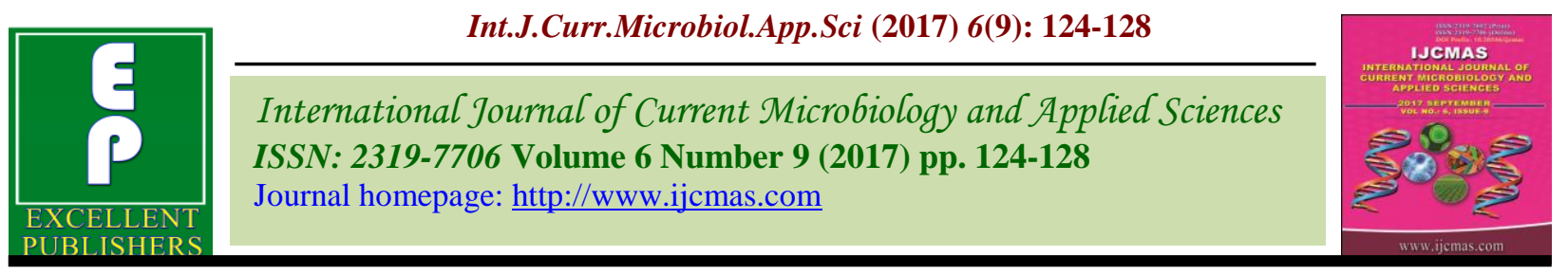

Original Research Article

https://doi.org/10.20546/ijcmas.2017.609.015

\title{
Comparative Efficacy of Different Trade Formulations of Buprofezin 25SC against Brown Plant Hopper in Rice
}

\author{
Vijay Kumar Soni ${ }^{1 *}$ and S.N. Tiwari ${ }^{2}$ \\ ${ }^{1}$ S. K. College of Agriculture and Research Station, IGKV, \\ Kawardha (Kabirdham) 491 995, Chhattisgarh, India \\ ${ }^{2}$ Department of Entomology, G.B. Pant University of Agriculture and Technology, \\ Pantnagar (U.S. Nagar) 263 145, Uttarakhand, India \\ *Corresponding author
}

\begin{tabular}{|c|c|}
\hline & A B S T R A C T \\
\hline & The experiment was conducted in glasshouse to compare the efficacy of \\
\hline & $\begin{array}{l}\text { Buprofezin } 25 \mathrm{SC} \text { insecticide sold by the different manufacturers under different } \\
\text { trade names against brown plant hopper Nilaparvata lugens } \mathrm{Stal} \text { ( } \mathrm{BPH}) \text { on rice }\end{array}$ \\
\hline $\begin{array}{l}\text { BPH, Buprofezin, } \\
\text { Efficacy, } \\
\text { Insecticide, Rice. }\end{array}$ & $\begin{array}{l}\text { cultivar TN-1 at Department of Entomology, G.B. Pant University of Agriculture } \\
\text { and Technology, Pantnagar, Uttarakhand, India for two cropping seasons during }\end{array}$ \\
\hline Article Info & different trade names viz., Applaud $\AA$, Lapa $\AA$, Java ${ }^{\circledR}$ and Apple $\AA$ by \\
\hline $\begin{array}{l}\text { Accepted: } \\
\text { 04 July } 2017 \\
\text { Available Online: } \\
\text { 10 September } 2017\end{array}$ & $\begin{array}{l}\text { manufacturers Tata Rallis India Pvt. Ltd., Syngenta India Pvt. Ltd., E.I.Du-pont } \\
\text { India Pvt. Ltd. and Dhanuka Agrotech Pvt. Ltd., respectively @ } 250 \text { g a.i./ha. and } \\
\text { an untreated control with three replication. Results revealed that Applaud® was } \\
\text { highly effective with maximum mortality } 97.8 \% \text { followed by Lapa }{ }^{\circledR}(96.0 \%) \text {, } \\
\text { Apple } \AA(89.4 \%) \text { and Java }{ }^{\circledR}(82.2 \%) \text { against BPH. }\end{array}$ \\
\hline
\end{tabular}

\section{Introduction}

Rice is one of the major food crops that provide necessary calories and nutrients to humans. Rice is mainly grown in almost all parts of the world. In Asia, the rice fields are mainly located in the Eastern, Southeastern and Southern regions where favourable warm and rainy conditions prevail. Hence, the main cultivators of rice are the countries of China, India, Indonesia, Thailand and Japan, which account for more than $90 \%$ of the total global rice production (FAOSTAT, 2006). Homopterous insect brown plant hopper $(\mathrm{BPH})$ is a important pests of rice in southeast and Far East Asia, because it causes direct damage by sucking plants sap which often results in the complete withering of the plants known as hopper burn and because it transmits viral diseases. In order to control $\mathrm{BPH}$, several resistant varieties of rice were released in some areas, but their success was limited by the appearance of biotypes of BPH. Thus, insecticides have been mainly used for the control of $\mathrm{BPH}$ in rice production. What makes it more difficult to control them is that they have developed resistance to organophosphates, carbamates and even to 
synthetic pyrethroids (Grayson et. al., 1990). So there is a need for chemicals which is most effective against $\mathrm{BPH}$, less toxic to mammals and effective at lower quantity will be the best substitute to older chemicals in integrated pest management. Wang et al., (2008) found that buprofezin is especially effective against homopteran pests, such as planthopper, with very low risks to environment including human beings.

Buprofezin is the first insect growth regulator (IGR) registered in the world for the control of BPH. It also shows high activity on homopterous pest insects such as rice planthoppers and leafhoppers without any adverse effects on their predators and parasitoids. Since the chemical inhibits larval molting, egg-laying and/or induces oviposition of unhatchable eggs, it suppresses the population density of hoppers even in the progeny of the treated generation with long lasting activity in the paddy field. Buprofezin causes no resurgence of hoppers by itself nor with the combination of other insecticides, working rather preventive. The safe properties on non-target organisms and the stable control effects on pest insects have led this compound to a prominent IGR for integrated pest managements in rice crop. Therefore, present investigation was carried out in glasshouse to compare the efficacy of Buprofezin 25SC insecticide sold by the different manufacturers under different trade names against brown plant hopper Nilaparvata lugens Stal. (BPH) on rice cultivar $\mathrm{TN}-1$.

\section{Materials and Methods}

The experiment was conducted in glasshouse to compare the efficacy of Buprofezin 25SC insecticide sold by the different manufacturers under different trade names against brown plant hopper Nilaparvata lugens Stal. (BPH) on rice cultivar $\mathrm{TN}-1$ at Department of Entomology, G.B. Pant University of
Agriculture and Technology, Pantnagar, Uttarakhand, India for two cropping seasons during kharif 2011 and 2012. The treatment includes the Buprofezin 25SC sold by the different trade names viz., Applaud®, Lapa ${ }^{\circledR}$, Java ${ }^{\circledR}$ and Apple ${ }^{\circledR}$ by manufacturers Tata Rallis India Pvt. Ltd., Syngenta India Pvt. Ltd., E.I.Du-pont India Pvt. Ltd. and Dhanuka Agrotech Pvt. Ltd., respectively @ 250 g a.i./ha and an untreated control with three replication. The test was conducted in plastic tray size of $42 \mathrm{~cm} \times 32 \mathrm{~cm} \times 7 \mathrm{~cm}$ with the following procedures:

\section{Mass rearing of brown plant hoppers}

A laboratory population of $N$. lugens were maintained on the plants of Oryza sativa L. (cv:TN1) in pots in glasshouse. The temperature of glasshouse was maintained from 25 to $30^{\circ} \mathrm{C}$ during the study period. The $2^{\text {nd }}$ and $3^{\text {rd }}$ instar nymphs of BPH from this culture were were used for the infestation.

\section{Seed germination}

The seeds of BPH susceptible cultivar TN-1 were kept on plastic petridish containing double layered moist filter papers. Water was added to seeds which were removed after 24 hours. Thereafter, petridish was placed in incubator maintained at $30^{\circ} \mathrm{C}$ temperature for efficient germination. Sufficient moisture was maintained in each petridish till germinated seeds were sown into tray.

\section{Preparation of seed bed for sowing}

The plastic tray $(42 \mathrm{~cm} \mathrm{X} 32 \mathrm{~cm} \mathrm{X} 7 \mathrm{~cm})$ was filled with well manured soil up to the sufficient height, so as to maintain $5 \mathrm{~cm}$ water level above soil surface. Soil was puddled properly and upper layer was leveled uniformly with the help of a smooth object to facilitate sowing. 


\section{Seed sowing and maintenance of seedlings}

The germinated seeds of $\mathrm{TN}-1$ were sown through broadcasting methods in plastic tray. After completing the sowing sufficient water was added daily up to the transplanting to ensure the healthy growth of seedlings.

\section{Transplanting of $\mathrm{TN}-1$ seedlings}

Twenty one day (21 day) old seedlings were planted in tray with a row to row spacing of 4 $\mathrm{cm}$ apart, whereas, distance between seedlings was kept at $3 \mathrm{~cm}$, so that, in each tray 10 rows could be accommodated and each row contained ten seedlings.

\section{Infestation of seedlings with BPH}

At 9 days after sowing (DAS) when the seedlings were 30 days old, trays were filled with $5 \mathrm{~cm}$ water level after which they were infested with 3rd instars nymphs of BPH from the $\mathrm{BPH}$ culture and total number of $\mathrm{BPH}$ nymphs per tray was counted.

\section{Insecticide dose calculation and application}

Different Four commercial formulations of Buprofezin 25SC were evaluated in this study in three replications. Each tray was considered as a single replication for each treatment. The dose of each insecticide and required water volume was calculated per hectare basis. The amount of each formulated insecticide was measured for the $500 \mathrm{ml}$ of water, and insecticide was dissolved separately in $500 \mathrm{ml}$ of water with proper mixing, before application. Twenty $\mathrm{ml}$ of spray volume was taken for the application to each replication of each treatment. In total, two applications were given at weekly interval by the hand sprayer.

The BPH population per tray was recorded before application and at the interval of 1,3 and 7 days after each application and the percent mortality of BPH was calculated. Number of dead insects was the basis for judging the effectiveness of insecticides. The data thus generated were analysed in Complete Randomized Design (CRD) using STPR-3 software and test of significance as per Gomez and Gomez (1984).

\section{Results and Discussion}

Comparative efficacy of different formulations of Buprofezin 25SC during Kharif 2011 is presented in table 1, which indicates that per cent mortality of $\mathrm{BPH}$ among various treatments ranged from 54.4 to $73.1 \%$ at 1day after Ist application. During this observation Applaud ${ }^{\circledR}$ gave the highest mortality $(73.1 \%)$ while lowest in Apple ${ }^{\circledR}$ (60.0\%). Lapa ${ }^{\circledR}$ and Java ${ }^{\circledR}$ showed 58.7 and 61.4 per cent while 54.4 per cent BPH died in untreated control. During this observation no significant difference was recorded in different treatments. After 3 and 7 days of Ist application mortality increased in all the treatments including untreated control. A further increase in the mortality was recorded at 1, 3 and 7 days after IInd application and during last observation it was significantly higher in case of Applaud $\AA$, Apple ${ }^{\circledR}$ and Lapa ${ }^{\circledR}$ as compared to Java ${ }^{\circledR}$ and untreated control. During kharif 2012 no significant difference in mortality of BPH was recorded at 1 day after Ist spraying in different treatment (Table 2). However, a wide difference was recorded in different formulations at 3 and 7 days after Ist application. At 3 and 7 days after Ist application Applaud $®$ and Lapa ${ }^{\circledR}$ showed significantly higher mortality as compared to Apple ${ }^{\circledR}$ and Java ${ }^{\circledR}$. A further increase in the mortality was recorded after IInd application in all the treatments. At 1, 3 and 7 days after IInd application Applaud ${ }$ and Lapa ${ }^{\circledR}$ showed higher mortality as compared to Apple ${ }^{\circledR}$ and Java ${ }^{\circledR}$. 
Table.1 Comparative efficacy of different formulations of Buprofezin 25SC against N. lugens under glasshouse condition during kharif 2011

\begin{tabular}{|c|c|c|c|c|c|c|c|c|c|}
\hline \multirow{3}{*}{ Chemical Name } & \multirow{3}{*}{$\begin{array}{l}\text { Trade } \\
\text { name }\end{array}$} & \multirow{3}{*}{$\begin{array}{l}\text { Manufa } \\
\text { cturer }\end{array}$} & \multirow{3}{*}{ Dose (g a.i./ha) } & \multicolumn{6}{|c|}{ \% BPH mortality } \\
\hline & & & & \multicolumn{3}{|c|}{ I application } & \multicolumn{3}{|c|}{ II application } \\
\hline & & & & 1DAS & 3DAS & 7DAS & 1DAS & 3DAS & 7DAS \\
\hline Buprofezin 25SC & Applaud® & Tata Rallis & 250 & $73.1(59.4)^{*} \mathrm{a}$ & 87.7(69.9)a & $91.4(73.1) \mathrm{a}$ & $98.0(82.1) \mathrm{c}$ & $99.2(85.2) b$ & $99.5(86.2) b$ \\
\hline Buprofezin 25SC & Apple® & $\begin{array}{l}\text { Dhanuka } \\
\text { Agritech Ltd. }\end{array}$ & 250 & $60.0(50.8) \mathrm{a}$ & 72.6(58.9)a & $84.0(67.6) \mathrm{a}$ & $95.3(77.6) b$ & $98.1(82.1) b$ & $99.1(84.5) b$ \\
\hline Buprofezin 25SC & Java $®$ & E.I.Dupont & 250 & 61.4(51.7)a & $70.9(58.0) \mathrm{a}$ & $82.8(65.8) \mathrm{a}$ & $95.2(77.4) \mathrm{b}$ & $97.9(81.7) b$ & 98.8(83.6)a \\
\hline Buprofezin 25SC & Lapa® & Syngenta & 250 & $58.7(50.1) \mathrm{a}$ & $82.7(65.5) \mathrm{a}$ & $88.5(70.2) \mathrm{a}$ & $\begin{array}{c}97.2(80.5) b \\
c\end{array}$ & $98.1(82.1) b$ & $99.1(84.7) b$ \\
\hline Control & - & - & - & $54.4(47.6) \mathrm{a}$ & $77.5(61.7) \mathrm{a}$ & $83.2(65.7) \mathrm{a}$ & $89.7(71.2) \mathrm{a}$ & $92.8(74.7) \mathrm{a}$ & 94.3(77.3)a \\
\hline S.Em. \pm & - & - & - & NS & NS & NS & 1.1 & 1.3 & 2.0 \\
\hline $\mathrm{CD}$ at $5 \%$ & - & - & - & NS & NS & NS & 3.6 & 4.3 & 6.4 \\
\hline
\end{tabular}

* Figures within parenthesis are angular transformed values. NS= Not significant. DAS = Day after spraying

Means followed by a common letter in a column are not significantly different from each other by DMRT

Table.2 Comparative efficacy of different formulations of Buprofezin 25SC against N. lugens under glasshouse condition during kharif 2012

\begin{tabular}{|c|c|c|c|c|c|c|c|c|c|}
\hline \multirow{3}{*}{ Chemical Name } & \multirow{3}{*}{$\begin{array}{l}\text { Trade } \\
\text { name }\end{array}$} & \multirow{3}{*}{ Manufacturer } & \multirow{3}{*}{$\begin{array}{c}\text { Dose } \\
\text { (g } \\
\text { a.i./ha) }\end{array}$} & \multicolumn{6}{|c|}{$\%$ BPH mortality } \\
\hline & & & & \multicolumn{3}{|c|}{ I application } & \multicolumn{3}{|c|}{ II application } \\
\hline & & & & 1DAS & 3DAS & 7DAS & 1DAS & 3DAS & 7DAS \\
\hline Buprofezin 25SC & Applaud® & Tata Rallis & 250 & $28.1(31.0) * a$ & $73.1(59.0) \mathrm{c}$ & $89.8(71.5) c$ & $92.7(74.4) \mathrm{c}$ & $96.0(79.1) \mathrm{c}$ & 97.8(83.9)c \\
\hline Buprofezin 25SC & Apple $®$ & $\begin{array}{l}\text { Dhanuka } \\
\text { Agritech Ltd. }\end{array}$ & 250 & $13.1(19.6) \mathrm{a}$ & $38.3(38.0) \mathrm{b}$ & $62.6(52.4) \mathrm{b}$ & $75.6(60.5) b c$ & $80.5(63.9) b c$ & $89.4(71.0) b c$ \\
\hline Buprofezin 25SC & Java ${ }^{\circledR}$ & E.I.Dupont & 250 & 7.6(15.8)a & $19.6(26.1) a b$ & $57.6(49.4) b$ & $70.4(57.3) \mathrm{b}$ & $75.3(60.4) b$ & $82.2(65.4) b$ \\
\hline Buprofezin 25SC & Lapa® & Syngenta & 250 & $13.4(21.4) \mathrm{a}$ & $71.2(57.6) \mathrm{c}$ & $87.4(69.1) \mathrm{c}$ & $91.2(72.8) \mathrm{c}$ & $93.6(75.3) b c$ & $96.0(78.5) b c$ \\
\hline Control & - & - & - & $3.8(11.1) \mathrm{a}$ & 9.9(17.9)a & $17.5(24.3) \mathrm{a}$ & $23.2(28.6) \mathrm{a}$ & $30.5(33.2) \mathrm{a}$ & $36.4(36.8) \mathrm{a}$ \\
\hline S.Em. \pm & - & - & - & NS & 4.3 & 3.9 & 3.8 & 4.4 & 4.8 \\
\hline $\mathrm{CD}$ at $5 \%$ & - & - & - & NS & 15.7 & 14.4 & 14.0 & 15.9 & 17.5 \\
\hline
\end{tabular}

* Figures within parenthesis are angular transformed values. NS= Not significant. DAS = Day after spraying

Means followed by a common letter in a column are not significantly different from each other by DMRT 
During last observation maximum mortality was observed in Applaud® (97.8\%) followed by Lapa ${ }^{\circledR}(96.0 \%)$, Apple ${ }^{\circledR}(89.4 \%)$ and Java ${ }^{\circledR}(82.2 \%)$. The present study is in line with the findings of Heinrichs (1984) who reported that buprofezin (Applaud) was highly selective and effective at low rates against nymphs of $N$. lugens, S. furcifera and Nephotettix virescens (Distant).Wang et al., (2008) reported that buprofezin was effective against homopteran insect pests, such as planthopper with very low risks to environment and human beings. He further, stated that buprofezin was recently recommended as one of the alternatives for highly toxic organophosphorous insecticides for controlling important insects on rice and also cautioned that over use of buprofezin might induce resistance. To avoid development of resistance to buprofezin, the chemicals may be alternated with other effective molecules.

Results revealed that Applaud® was highly effective against BPH followed by Lapa ${ }^{\circledR}$, Apple® and Java ${ }^{\circledR}$.

\section{References}

FAO STAT, 2006 http://faostat.fao.org/default.aspx

Gomez, A.K., and Gomez, A.A. 1984. Statistical procedure for agricultural research. Int. Rice Res. Inst., Los Banos Philippins.

Grayson, B.T., Green, M. B. and Copping, L. G. 1990. Buprofezin; a Reliable IGR for the Control of Rice Pests. Pest Management in Rice. pp. 210-222.

Heinrichs, E.A., Basilio, R. P., and Valencia, S. L., 1984. Buprofezin, a selective insecticide for the management of rice planthoppers (Homoptera: Delphacidae) and leafhoppers (Homoptera: Cicadellidae). Environ. Entomol, 13: 515-521.

Wang, Y., Gao, C., Shen, J., Zhang, J., Huang, Y., Li, W., Dai, D., Zhuang, Y. and Zhou, W., 2008. Buprofezin resistance selection, susceptibility survey and analysis of fitness costs in Nilaparvata lugens (Homoptera: Delphacidae). Manage Sci., 64: 10501056.

\section{How to cite this article:}

Vijay Kumar Soni and Tiwari, S.N. 2017. Comparative Efficacy of Different Trade Formulations of Buprofezin 25SC against Brown Plant Hopper in Rice. Int.J.Curr.Microbiol.App.Sci. 6(9): 124-128. doi: https://doi.org/10.20546/ijcmas.2017.609.015 